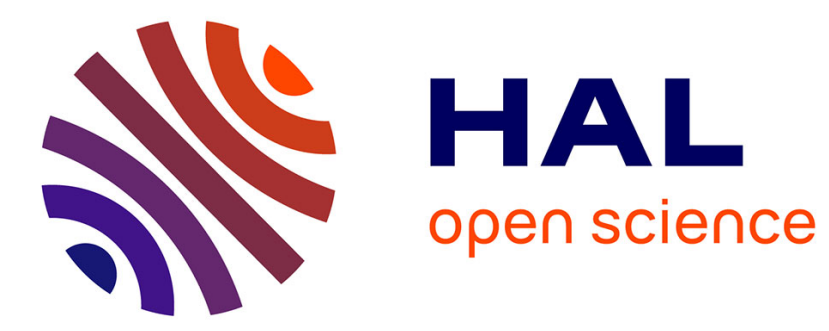

\title{
'Fusion' Performing Arts: a Plea for Diversity
}

Bernard Bel, Andréine Bel

\section{To cite this version:}

Bernard Bel, Andréine Bel. 'Fusion' Performing Arts: a Plea for Diversity. Interface, Journal of New Music Research, 1992, 21 (3-4), pp.263-280. hal-00311306

\section{HAL Id: hal-00311306 https://hal.science/hal-00311306}

Submitted on 13 Aug 2008

HAL is a multi-disciplinary open access archive for the deposit and dissemination of scientific research documents, whether they are published or not. The documents may come from teaching and research institutions in France or abroad, or from public or private research centers.
L'archive ouverte pluridisciplinaire HAL, est destinée au dépôt et à la diffusion de documents scientifiques de niveau recherche, publiés ou non, émanant des établissements d'enseignement et de recherche français ou étrangers, des laboratoires publics ou privés. 


\title{
“Fusion" Performing Arts: a Plea for Diversity
}

\author{
Bernard \& Andréine Bel
}

\begin{abstract}
The authors are proposing an approach to creative forms of performing arts allowing diversity and unity to coexist. In their view, this is possible through a cross-fertilization of Western and nonWestern cultures in which the main theoretical and practical knowledge sources would derive from cognitive anthropology and the experience acquired by learning from acknowledged masters. Having questioned the role of "ethno"-sciences in this process, they discuss analytical methods in research on music/dance, such as space categorizations and movement transcription. They suggest that composers and choreographers should work together to render explicit certain fundamental aspects of their knowledge, more specifically those relating to experiences of time. In the end they outline an old cognitive theory of suggestive expression in music/dance/drama performance which comes in support of recent work in anthropology of the arts.
\end{abstract}

\section{Keywords:}

Music and movement transcription, conceptions of time, cognitive musicology/choreology, ethnomusicology, ethnochoreology, anthropology of performing arts, aesthetics, intercultural artistic production.

[...] d'âge en âge, quelle que soit la distance du temps, ou de continent à continent, quelle que soit la distance d'espace, une voix d'homme, quelle que soit sa langue, quand elle parle d'une certaine façon, peut toujours être entendue par une oreille d'homme, s'il y a quelqu'un derrière pour l'écouter.

(Armel Guerne, preface, Kawabata 1960, pp.16-17)

We are advocating the recognition of a new trend in contemporary art that we labelled "fusion" music/dance/drama/... to distinguish it from World Music and musiques/danses métissées in the French-speaking community. We mean by this creative work in the Western performing arts enriched by highly sophisticated musical, choreographic and dramatic techniques borrowed from outside the Western world (or vice-versa).

Here in France we have observed an increasing demand for presentations of nonWestern performing arts uninfected by folklorism or the naive "musique/danse sacrée" labelling of many so-called traditional repertoires (Schechner 1991). We resent this since it appears to be a strategy designed to get rid of the ideology of "authenticity": this first originated in rock music (Frith 1991), and it still constitutes the main marketing argument for both traditional and contemporary art forms. Because it valorizes emotional reactions against analytical, critical and reflexive activities - a "romanticization of art as a transcendant category" (Nelson 1992) - the ideology of authenticity tends to inhibit (selfcritical) explorative work in art production. We regret, for instance, that too many performances of contemporary dance in Western Europe have become predictable and self-imitative because formalist approaches (Brightman 1984, p.10) are restricted to 


\section{B. \& A. BEL}

combinatorics on conventional situations, while expressive approaches tend to fall into the intériorisation du mouvement cliché.

We feel that cultural cross-fertilization may be a good way of reconciling sensitive and intellectual aspects of art production, promoting the idea of "open cultural systems" in the sense of Morin (1990). An important aspect of this openness is the relation of music to other performing arts. Our assumption is that the knowledge of Western contemporary musicians (e.g., their skill in handling so many conceptions of time) remains a remarkable, yet unexplored, source of inspiration for creative dancers/choreographers.

\section{"FUSION" IS NOT CONFUSION}

Traditional music from several parts of the world has exerted an increasing influence on Western music during the last decades because of the growth of the audio recording market. Nevertheless, "East meets West" encounters, most popular in the 1960s and 1970s, have had ephemeral success. Sitar maestro Pandit Ravi Shankar, a leading figure in these encounters, recently expressed a feeling shared by many Indian musicians:

Il n'y avait rien de solide. La preuve, tout cela a maintenant disparu. Il en reste peut-être quelques jolies mélodies, des Beatles par exemple. Aujourd'hui, dans la new wave et la musique contemporaine occidentale, il y a des formes bien plus intéressantes. (Shankar 1991, p.23)

The same opinion was already predominant among participants in the East-West Music and Dance Encounters held in Bombay in 1983-84. ${ }^{1}$

In the late 1980s, the label "World Music" was invented to promote sales of miscellaneous records of ethnic music (Krumm 1991, Labesse 1991, Frith 1991). It is legitimate to predict that part of the future market of video discs may be devoted to "World Dance" or the like, an important challenge for Western dancers/choreographers (A. Bel 1992a-b).

A long exposure to exotic sounds, and encounters with outstanding traditional performers, have enabled Western music composers to open their repertories to extraEuropean instruments and their associated composition/improvisation techniques. Unfortunately this is not yet the case with most European choreographers who never had the chance to meet acknowledged dance masters from Eastern and African countries, thereby feeling comfortable with the belief that creative art is exclusively Western. A puff of fresh air came with the International Seminar on Choreography organized in New Delhi by Sahitya Kala Parishad (November 30 to December 2, 1989) bringing together choreographers from India and several Western countries. All participants benefited from a real confrontation with divergent points of view on choreography and scenography.

Fusion music is already a reality under various labels, with a tremendous growth potential thanks to the availability of ethnomusicological data. It may also be the outcome of local interactions, as exemplified by Sardinian composers Franco Oppo, Marcello Pusceddu, Lucio Garau,..., influenced by their own traditional music. On the other hand, fusion dance has remained a rare species because there seems to be too little interest (and presumably no money) in the academic world for ethno-dance studies beyond the compilation and analysis of folklore. Among prominent attempts to collect data about choreographic and scenographic experience in other cultures we may cite a detailed (still unpublished) study by choreographer Susan Buirge, and a very informative book published by the International School of Theatre Anthropology in Denmark (Barba \& Savarese 1991). 
In our view, productions by Indian choreographer Astad Deboo, who first trained in Kathakali and Kathak dance styles and later in a variety of Western dances (ranging from Martha Graham and Jazz to Pina Bausch), are typically representative of "fusion" art. Deboo's modern dance style is a blending of Indian and Western elements (Bhabha \& Lechner 1984, pp.19-20). It is a personal and multi-facetted style because of the impressive variety of knowledge resources at the artist's disposal. Among the creative artists most acclaimed in Europe we would cite Ushio Amagatsu, a Butoh dancer who founded the Sankai Juku dance company in 1975. Butoh and related dance forms are generally not classified as contemporary dance forms, even though Amagatsu himself (unlike, for instance, Koichi Tamano) does not refer to a "Butoh tradition". Undoubtedly, Western audiences tend to force exotic labels on techniques that do not comply with local conceptions of contemporary art. The right question, therefore, may be: "on what cultural common ground rests the internationality of the contemporary dance?" (Bhabha \& Lechner 1984, p.7)

It may be meaningful to notice that Butoh was not enlisted in Ohtani's (1992) detailed report on Japanese dances. ${ }^{2}$ These points lead us to say that sophisticated hybrid forms acquire an identity outside their original cultures. They do not make it a point to express cultural differences, as it was the case with World Music. Altogether, unlike Global Music, they do not claim "to dissolve or deny national boundaries and differences" (Frith 1991).

Fusion is not confusion: it is rather a hybridization process allowing diversity and unity to coexist (Cogan 1991), perhaps an opportunity for the so-called "avant-garde" to shift from a closed, self-imitative (and self-contemplative) thinking about art, to one which Edgar Morin (1990, pp.11-12) termed as "pensée multidimensionnelle",

[...] animée par une tension permanente entre l'aspiration à un savoir non parcellaire, non cloisonné, non réducteur, et la reconnaissance de l'inachèvement et de l'incomplétude de toute connaissance.

\section{The end of ethno-music/dance?}

Regarding "ethnic music", the late John Blacking (1989b, p.17) wrote:

The rhethoric surrounding the term suggests that there is a belief that social groups can capture and understand the 'spirit' of their collective life through quasi-mystical acts of communal creativity.

This leads to the belief that the music categorized as "ethnic music"

[...] was apparently not created by great composers. [...] There is, of course, a sense in which the works of Bach, Schubert, Debussy, Vaughan Williams, or any named composer, could be described as 'ethnic' music. The 'ethnicity' of Bach's music needs to be taken into account as much as the individuality of an African traditional composer [...] (ibid.)

Is there any reason why musicians playing traditional instruments - even the ones with exotic names or strange appearances - cannot (should not) produce music outside their traditional repertoire? Or is it that we decided once and for all that they must content themselves with preserving a storehouse of "authentic" (yet somehow fossilized) knowledge? This cultural bias recalls the viewpoint of musicologists who take it for granted that Italian music of the fifteenth century was "archaic" because it was based on old techniques, whereas a composer like Guillaume Dufay, in some of his works, created new forms of musical thinking, undoubdtedly representative of the nascent Italian Renaissance civilization. (Vecchione 1992) 
Native scholars are often irritated by the ethnocentricity of the "ethnic" approach. Famous Sanskrit musicologist Mukund Lath (1988) raised the point:

$[\ldots]$ the banner "ethnomusicology" [...] has certain unsavoury suggestions and echoes of references to a comparatively "lower" art, practised by traditional, "third-world" communities, stagnant rather than creative. One would not write about Western classical music under this banner [...]

An elaborate definition of ethnomusicology might be the answer. In Nettl's view (1989), ethnomusicology is

[...] the comparative study of musical systems and cultures; the study of music in or as culture; the study of a musical culture from an outsider's perspective. None of these excludes the art music of Western society, but few ethnomusicological studies have actually been devoted to it.

Nettl's definition does not justify the "ethno" prefix, so why not call it "musicology", as suggested by Lath (1988)? ${ }^{3}$ There seems to be a fertile ground for a new science of music overlapping cognitive science(s), psychology, sociology and philosophy of the arts:

I never thought of ethnomusicology as a separate subject, since I believe it can just as well be called cognitive anthropology [...] I believe we may be able to take the "ethno" out of ethnomusicology before long. Then we may once more have a unified musicology, a musicology truly fertilized and enriched by the contributions of ethnomusicology. (Blacking 1989a)

There is historical evidence that early studies in ethnomusicology (at that time it was still called "comparative musicology"), although lacking explicit formal models, were actually aiming at a cognitive inquiry. As put by Bor (1988, pp.64-65),

[...] the preoccupation of early 20th century comparative musicologists with "scientific" research in the laboratory, and their emphasis on collection and preservation of traditional music, has obscured the fact that there is a clear correspondence between the founders of "modern" ethnomusicology and the 17th, 18th and 19th century travellers, Oriental scholars and music historians. [...] The fact remains that comparative musicologists became so entangled in comparing different musical systems, and were so elated with their "young science", that they lost sight of their predecessors, several of whom had acquired a more profound knowledge of the subject than themselves.

\section{Expert knowledge is with native masters}

At first sight, advocating an "outsider's perspective" on musical culture - the "ethnomusicologist from Mars" (Nettl 1989) — does not seem compatible with a cognitive approach, the aim of which should be

to grasp the native's point of view, his relation to life, to realize his vision of his world. (Malinowski 1922, p.25. Also see Kippen in this volume.)

The outsider's perspective may be understood as managing to distance oneself from speech knowledge about cultural systems, the more so (as illustrated in Nettl's paper) when the analyst is born in the very culture under investigation. A significant part of speech knowledge is a mythical reconstruction of major historical events in the life and production of individual artists or communities of art practitioners (Schechner 1991, Nettl 1989). This amounts to distinguishing what a performing artist (or composer) is doing from what he says he does, what he thinks he does, and what he aims to do.

Knowledge modelling is often considered as the first step of knowledge-base engineering, restricting it to narrow technical goals (Laske 1992), whereas it should be preceded by several phases involving anthropological activities: knowledge assessment, elicitation and analysis (ibid.). In fieldwork these important preliminary stages can be 
worked out in great detail if models are elaborated and evaluated by informants themselves, as suggested by Blacking in his idea of dialectical anthropology (Blacking 1985, Kippen 1985), thus reconciling knowledge modelling with Malinowski's point of view. We have shown that, when facts and rules lend themselves to computer representations, the dialectical approach may be carried out on the basis of formal models implemented in some kind of expert system (Kippen \& Bel 1989a, 1992). Nevertheless, the modelling of actual artistic performance may call for sophisticated automatic knowledge acquisition techniques (Kippen \& Bel 1989b, Kippen 1992).

Building (formal or informal) performance models of music/dance for tasks other than strictly academic (documentation, analysis, preservation) implies investigating the specificity of individual performance, as it points at cognitive aspects that are of prior importance in grasping the essence of the art of composing. For us, "fusion" music/dance comes into existence only when composers and choreographers are given access to the know-how of those artists who are acknowledged as great masters in their own culture (or, at least, recognized as experts regardless of their social status — see Blacking 1989b).

\section{THE ANALYST'S POINT OF VIEW}

\section{Spatial directions}

Dance notation, already an essential tool for dance research, might become increasingly important at a time choreographers are given access to dance composition software. However, the extensive use of transcribed material may also preclude attempts to build theories of human movement outside Western culture (from which the major notation systems originated). In a remarkable account of the work by Japanese dance scholars, Kimiko Ohtani (1991) mentioned studies investigating movement from an in-depth "emic" perspective, e.g. the search for "nuclear movements" determining the styles of dances (Kikkawa 1989, quoted by Ohtani 1991). Similarly, part of our research on raga melodic movement has been an attempt to determine basic melodic patterns characteristic of raga/performer/style (Arnold 1984, Arnold et al. 1984, Bor et al. 1984, Rao \& Biswas 1990, Rao 1992).

Any scientific work on music/dance requires a preliminary investigation of the very complex parametrization problem. In 1989 we had a discussion with Myriam Phillips, an ethnochoreologist who had undertaken a comparative study of Flamenco and North Indian Kathak dance. She told us that her analytical work was based on scores in Laban kinetography, in which she had to divide the horizontal plane in twelve equal angles. We pointed out that Kathak dancers make use of sixteen directions, a fact that she had not been taught during her stay in India. Ignoring spatial directions in Kathak is as dramatic as singing out of tune. All Gypsy dancers we observed in Seville seemed to follow the same system, a fact that still should be confirmed by their teachers, because a scaling of space directions makes no sense unless it is explicitly used in dance composition.

\section{Movement analysis}

Although we approve of efforts aimed at movement transcription, so far as they generate new task environments for creative choreographers (see for instance Brightman 1984, 1989), we would question the attempts of ethnochoreology to establish itself as a science on the basis of the same paradoxical position as ethnomusicology. In this position we find anthropological insights, e.g. 
[...] movement (and sound) are often dimensions of ritual and social activities, and cannot be classified with European concepts [...]

(Giurchescu, Kaeppler \& Torp 1992, preface)

mixed with the belief that a transcultural meta-model will emerge from a systematic processing of (presumably universally valid) transcriptions. Referring to any Western music/dance transcription as a "universal" system might bring us back to 18th century ethnography, when Hamilton Bird published collections of Indian songs adapted for the harpsichord, complaining that it had

[...] cost him great pains to bring them into any form as to TIME which the music of Hindostan is extremely deficient in [...] (Cited by Bor 1988, p.56)

Considerable work can (and should) be undertaken in the field of comparative dance studies, despite the shortcomings of transcriptions which have been pointed out. In these strangely related dance forms, Flamenco and Kathak, the use of eye and wrist movements, neck and hip positions, have more practical relevance than theoretical constructs describing their choreographic repertoires.

As far as archival/analytical work is concerned, we believe that new video techniques will soon render movement transcription techniques obsolete. Unlike sounds, spatial events retain their inner consistency when scanned at different speeds. Therefore, with the help of hypermedia (computer-controlled laser disk storage and retrieval of pictures and sounds) it will be advantageous to examine movements from different angles (on different windows) and modify time scales down to still pictures. The analyst will then be free to design a task-specific symbolic transcription on the basis of his/her understanding of the technique.

\section{A parallel with melodic analysis}

Analyzing video recordings makes it evident that dance movements are not just successions of postures, in the same way a melodic line is not necessarily a succession of notes with some kind of "ornamentation". Fig.1 shows a short melodic line transcribed with the Melodic Movement Analyzer above its notation in Western staff notation (Bel \& Bor 1985). The bottom line is the Indian Sargam transcription (using abbreviations for the names of notes: $\mathrm{Sa}, \mathrm{Re}, \mathrm{Ga}, \mathrm{Ma}, \mathrm{Pa}, \mathrm{Dha}, \mathrm{Ni}$ ) complemented with special symbols representing melodic connections. 

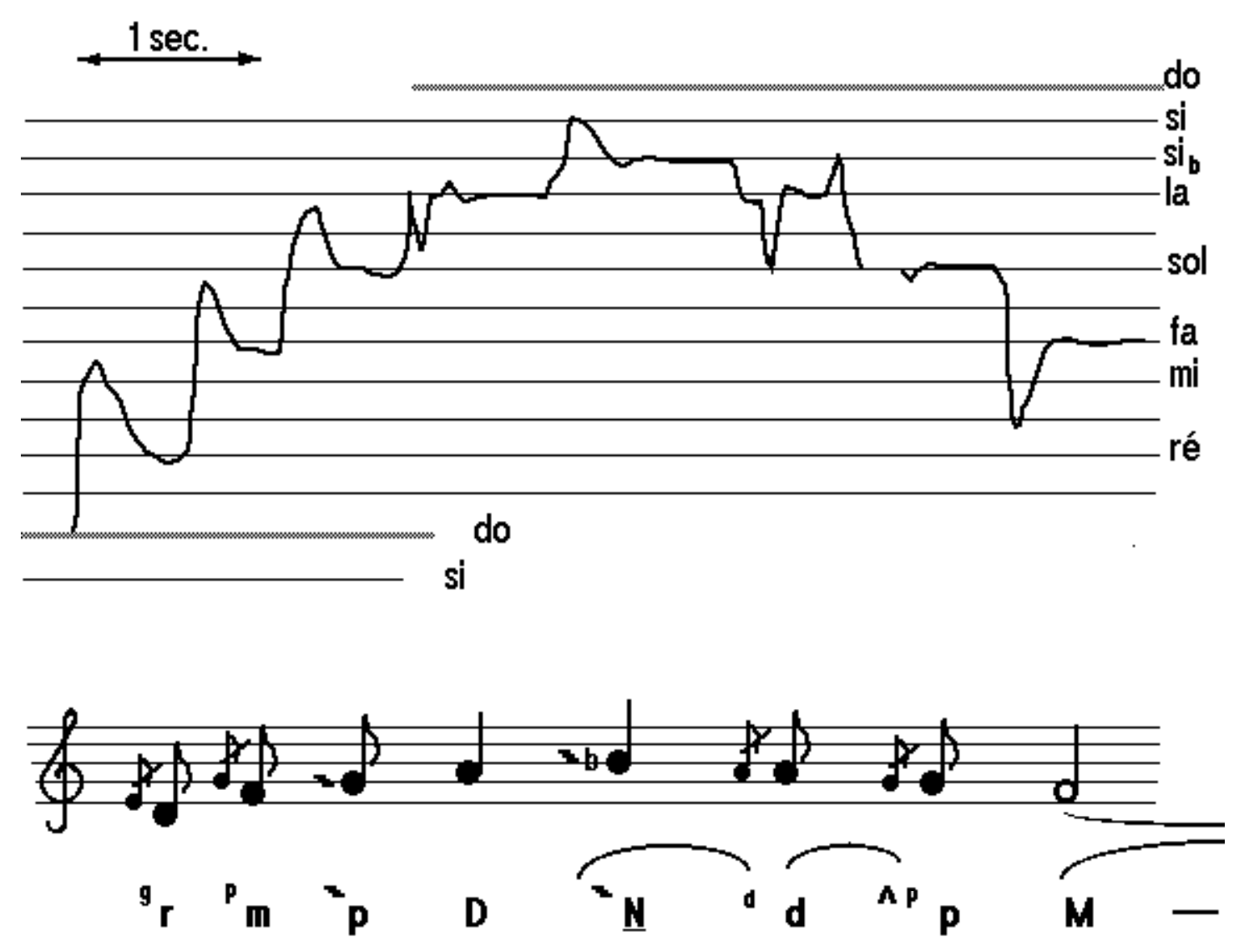

Fig.1 Raga Asha, composition by Pandit Dilip Chandra Vedi sung by Ms. Bhupender Seetal (fragment)

In the ascending part of the melodic line there is no obvious way to distinguish notes (as recognized by a trained listener) from grace notes and melodic connections. However, using an ad hoc (raga independent) morphological model of melodic movement (Van der Meer \& Bel 1986) it is possible to deduct the symbolic transcription (bottom line) accurately from melodic data only. Here the result corroborates observations by Castellengo (1991) suggesting that the final phase of a very short vibrato is often predominant in pitch determination.

Work on the morphology of raga melodic movements, although still in its infancy, points at the complexity of human-manufactured movements even when only one parameter (such as measured pitch) is considered. A scientific analysis of body movement (such as computer simulations aimed at improving the efficiency of athletes) requires the further consideration of data about physical and human bodies, rules of theoretical mechanics, and a clear definition of the task(s) to be achieved in each movement. In other words, formal approaches to dance movement may be envisaged only on the basis of a detailed knowledge base of kinetic concepts, prototypical movements, etc. - the very kind of information dance researchers dream of finding in a formal study... Solving such a dilemna may imply linking cognitive science (studies in body movement and perception) with semiotics (Williams 1981), an endeavour that goes far beyond current analytical tasks in dance research. (This also requires an enormous amount of money. Unlike sportsmen/women, choreologists do not easily find sponsors!) 


\section{Non-metric space: microtonality}

It is well known that pitch and time representations in Western conventional music notation are derived from categorizations of intervals referring to metric spaces (equaltempered intervals and metronomic timings). Musicologists are less aware that many theories of "microtonal" intonation are also implicitly metric. Their basic (wrong) assumption is that if tonal intervals are mapped to integer numbers with additive properties, then all intervals must be multiples of a same unit.

This assumption has biased most interpretations of the scale theory exposed in the old Indian treatise Natya $\sum_{\text {astra }}$ (Bharata 1929). In fact, from the "two-vina experiment" described by Bharata (Bel 1988a-b) one can only infer that intervals named "1-sruti, 2sruti, etc." are of increasing sizes, and that two intervals with identical names can be matched by transposition. In other words, Bharata's statements alone do not imply that the " $\mathrm{x}$ " srutis in a "x-sruti" interval must have equal sizes (although they might).

The discussion of experimental data in the appendix may shed light on the extreme complexity of modelling even those aspects of music that have been studied in depth by local musicians (who claim consonance to be the deep foundation of North Indian raga).

\section{Multiple conceptions of time in music and dance}

I personally have come to question, if not reject, the assumption of unity as a primary value. The case can easily be made that we currently require models not of unity, but of successful diversity, plurality, and multiplicity, corresponding to the multifaceted cultural, historical, and methodological actualities that surround us. (Cogan 1991)

Studying perceptions and representations of time at various epochs, or even within the productions of one single composer (Esclapez 1992), is one of the most fascinating challenges faced by anthropologic-cognitive musicology/choreology. For instance, Baroque musicians interpreting non-measured harpsichord preludes did not locate musical events with the same care for "ordering" and "simultaneity" as imposed by our present sensibility to time (Servant 1992). Similar facts may be still observed in the performance of North Indian music, most evidently in light-classical thumrir singing: although a regular metric cycle is set by the drum player, both the singer and sarangi player are evolving on more flexible time structures. ${ }^{4}$ Western musicians may perceive the resulting complexity as chaos, but it plays an essential role in the proper poetic rendering of this style of music. The ability to handle multilayered time structures (by developing a "multilayered awareness" of time) has been termed "polychronicity" by Hall (1983) and further elaborated by Grossin (1988). 5 
Fig. 2 KSHANA

(Choreography: Andréine Bel. Music: André Mouret)

Polychronicity is also an important aspect of African musics (Oertli 1990). In Western dance, the question of metric/non-metric time is generally addressed from a monochronic perspective... In this context, Isadora Duncan's search for "natural rhythm" (Duncan 1977) must have been perceived as antisocial in a world dominated by 19th century quantified time (Grossin 1988). Modern dancers tend to reject Duncan's approach along with the ideology of "natural movement", but we suggest that another deep reason may be that non-metric and metric conceptions of time cannot coexist on a monochronic substrate (A. Bel 1992b).

The 20th century has witnessed a profound interest of Western composers in new conceptions of time. Altogether, interactions between movement and sound on a polychronic substrate are not so obvious and remain to be explored, as contemporary Western dance is still at the initial stage of systematically dissociating music and movement. Indeed, we know dancers who developed this faculty in their approach to " $l a$ musicalité du mouvement" (to quote Maïté Fossen, personal communication), but in most cases music, as a sound construct, remains at the back of the stage. Interactions between music and movement (at the structural level) have been investigated extensively in our solo dance item "Zindegi". In one of the scenes men were heard singing classical music on a boat, undisturbed by the boatman singing his favourite film song (strongly out of tune). The classical song, the film song and the river and boating sounds were actions taking place in "separate", yet interrelated, times. The last scene featured a secluded 


\section{B. \& A. BEL}

woman's state of indecision between self-achievement and madness. Its polychronicity was incidental: the sound track was a mixture of a classical dance song with a recording of street sounds displaying many (objectively independent) layers such as bird calls, temple bells, factory noise, trains, trucks.... In highlighting synchronicity (Jung 1950) between the different layers, our choreography was meant to provoke the awareness of contradictory moods experienced by the woman, i.e. "a peculiar interdependence of objective events among themselves as well as with the subjective (psychic) states of the observer or observers" (op.cit., p.xxiv).

To us, shifting from polyrhythms (for which classical Kathak is famous) to polychronicity has opened the way to new choreographic techniques, a task that became feasible only through an exposure to Western contemporary music, notably André Mouret's intricate rhythmic system (Allouche \& Mouret 1988) and works like Dialogue en 7 (1982), Ressac (1987) and Myriades (1991). We believe that a new type of collaboration between contemporary choreographers and composers remains to be invented, one in which music will not be just an optional background element of the dance performance.

\section{THE PERFORMER'S POINT OF VIEW}

Recently we had the pleasure of attending a performance of Amagatsu's ballet "Unetsu" (created at Théâtre de la Ville in Paris, 1986). Sharing impressions with friends revealed that each of them (equally fascinated by the show) had perceived an entirely different "story". Opposite to this is the performance of most South Asian dances in which codified expression is predominant. Auditors ignoring the codification system have the impression that because they cannot grasp the explicit meaning of the piece they are certainly missing its aesthetic content. In fact, both contemporary and traditional arts become "exotic" when they rely too much on explicit meanings.

We feel that many artists fail to understand the cognitive processes underlying performance itself and its relation to explicit or implicit meanings. According to Indian theorists of performing arts, expression may be literal (abhida), metaphoric or metonymic (laksana) and suggestive (vyanjana), the latter being the domain of "pure poetry". A theory of suggestive expression was elaborated in the context of Kashmiri shaivism, a complex philosophical system at the confluence of several religious trends (among which tantrism and sufism). The theory was initiated by art philosopher Anandavardhana during the 9th century and fully developed by Abhinavagupta in the early 11th century (Walimbe 1980).

Anandavardhana's premise states that artistic production is primarily a recombination of existing elements (Lath 1984 p.50, A. \& B. Bel 1990). However, novelty is not so much a matter of finding new primitive objects or combinations: even the same performance watched several times may be perceived as "new" if certain conditions are met. A necessary condition for experiencing rasa (aesthetic pleasure as a "gustative process") is a sufficient degree of imprecision, an incompleteness of the codification triggering the imagination (kalpana) of each auditor, thereby yielding a "second creation" (bhavana) within the field of the "unspoken". Anandavardhana makes it clear that this process is not the outcome of a semantic operation (Lath 1984, p.49). Later, 11th-century writer Abhinavagupta related dhvani to the activation of remainders of past experience called karma. Karma itself is the accumulation of "life roots" (vasana), a profound dissatisfaction linked to every action in itself. 
Impressive examples of dhvani are found in Western culture. In Jiri Kylian's ballet on Stravinsky's L'histoire du Soldat, the main character wraps himself in a golden cloth (a metaphor for the luxury provided by his pact with the Devil). On the video the scene is shot from above. In the end, the position of the dancer and the cloth remind us of a fœtus, somehow evoking the desire to undo his (our?) past life.

Suggestion is also a basic technique used by publicity, sometimes even provoking the experience of dhvani. Recently, a poster (advertizing a brand of Scotch whisky) depicted a young couple sitting on the roof of a train heading towards the mountains at sunset. The emotion conveyed to us by the picture might be related to the rememberance of a past (forgotten) situation connecting snowy mountains, sunset, a train and some love story —not unlike the one depicted by Japanese poet Yasunari Kawabata (1960, p.27):

[...] tout se maintenait en une unité fantastique, tant l'immatérielle transparence des figures semblait correspondre et se fondre au flou ténébreux du paysage qu'enveloppait la nuit, pour composer un seul et même univers, une sorte de monde surnaturel et symbolique qui n'était plus ici.

Suggestive expression is difficult to capture in analytical work because it is based on the activation of the (unbound) listener's memory. In North Indian classical music, a phrase of a given raga may evoke (to educated listeners) several neighbouring ragas without "touching" them.

The rasa-dhvani theory fits perfectly with Ferdinando Taviani's conception of drama performance. In his view, the very fact that theatre is an art and not a mere projection of daily life is the result of a necessary distance between the actor's and (each) spectator's visions:

In short, simple common sense obliges us to recognise that to understand a performance does not only mean to see what its authors (performers, director, playwright...) have put into it, and that to understand it profoundly does not mean to discover what has been hidden deep within it, but rather to make discoveries during a carefully studied journey.

This is equivalent to saying that 'to make a performance understood' does not mean to plan discoveries but to design, to lay out, embankments along which to make a minute, multiform, unforeseen life appear on these embankments.

(Taviani 1991, p.256)

\section{ACKNOWLEDGEMENT}

Although this paper is based on many years of shared interest in music, dance and related scientific topics, it should be understood that most technical issues on music and dance have been raised by Bernard and Andréine Bel respectively. We also feel very indebted to Jim Kippen for his assistance in discussing the paper and to Susan Buirge for her inspiring work and advice. 


\section{NOTES}

1 Jointly organized by Dr. Georg Lechner(Goethe Institute), Jamshed J. Bhabha (National Centre for the Performing Arts), Alliance Française and the British Council.

2 In a personal communication (28/3/92), Ohtani Kimiko mentioned the existence of several Japanese dance styles "based on traditional dance with Western influences, among which Butoh is one of the successful ones."

3 In Ethnomusicology Research Digest 82 (10 April 1992), Michelle Kisliuk pointed out that SEM President Mark Slobin had initiated a discussion regarding alternative names during the 1991 Seminar for Ethnomusicology.

4 e.g. Kishori Amonkar's “Koyaliya Na Bolo Dar Dar” (cassette recording HMV 6TC 04B 3916)

5 In our view, Hall's categorization of cultures as monochronic/polychronic is oversimplistic, but polychronicity remains an essential paradigm for the study of performing arts.

\section{REFERENCES}

Allouche, J.P., \& A. Mouret (1988). Libertés non anarchiques, automates finis et champs matriciels. In (B. Vecchione, ed.) Actes du Colloque "Structures Musicales et Assistance Informatique”, CRSM-MIM, Aix-en-Provence/Marseille, 45-50.

Arnold, W.J. (1984). Playing with intonation. ISTAR Newsletter, 3-4, 60-62.

Arnold, W.J., J. Bor, \& W. Van der Meer (1984). On Measuring Notes. A response to N.A. Jairazbhoy. ISTAR Newsletter, 3-4, 46-51.

Barba, E., \& N. Savarese (eds.) (1991). The Dictionary of Theatre Anthropology: the Secret Art of the Performer. London/New York: Routledge.

Bel, A. (1992a). Kathak "fusion": une voie nouvelle pour la création chorégraphique contemporaine. Telex Danse, 43. Paris: Fédération Française de Danse, 13-15.

Bel, A. (1992b). De la danse Isadorienne à la danse "fusion", en passant par le Kathak. Rapports musique/mouvement, suggestion poétique, formes polychrones. International seminar The Relevance of Isadora Duncan's Teachings to Contemporary Dance Production. La Ciotat (France): ARRC/FEDALI.

Bel, B. (1988a). A mathematical discussion of the ancient theory of scales according to Natyashastra. Internal report 272. Groupe Représentation et Traitement des Connaissances, Centre National de la Recherche Scientifique, Marseille.

Bel, B. (1988b). Raga: approches conceptuelles et expérimentales. In (B. Vecchione, ed.) Actes du Colloque "Structures Musicales et Assistance Informatique", CRSM-MIM, Aix-en-Provence/Marseille, 87-108.

Bel, A. \& B. (1990). Activité créatrice transformationnelle: théorie et pratique. In (B. Vecchione \& B. Bel, eds.) Le Fait Musical - Sciences, Technologies, Pratiques. Prepublication of the Acts of the Conference "Music and Information Technology", Aix-en-Provence/Marseille: CRSM-MIM, 193-206.

Bel, B. (1991). Equipentatonic tunings. Ethnomusicology Research Digest, 38 (18 March), lines 57-114. Electronic file retrievable as ERD 91-038 by anonymous ftp from info.umd.edu, directory ReadingRoom/NewsLetters/EthnoMusicology/Digest.

Bel, B., \& J. Bor (1985). NCPA/ISTAR Research Collaboration. NCPA Quarterly Journal, 14, 1. Bombay: National Centre for the Performing Arts, 45-53.

Bhabha, J.J., \& G. Lechner (1984). Dance Encounter: the Western scene. NCPA Quarterly Journal, 13, 2. Bombay: National Centre for the Performing Arts, 5-7.

Bharata (1929). Natya Shastra. Benares: Kashi Sanskrit Series, 60.

Blacking, J. (1985). Dialectical ethnomusicology: making sense of Ellis and Adler in 1985. European Seminar of Ethnomusicology, Queen's University of Belfast, 23-28 march. 
Blacking, J. (1989a). Interview with Keith Howard. Queen's University of Belfast, 2830 september. Electronic file retrievable by anonymous ftp from info.umd.edu, directory ReadingRoom/Newsletters/EthnoMusicology/Archive.

Blacking, J. (1989b). Challenging the myth of 'ethnic' music: first performances of a new song in an African oral tradition, 1961. Yearbook for Traditional Music, 21. New York: International Council for Traditional Music, 17-24.

Bor, J. (1988). The rise of ethnomusicology: sources on Indian music c.1780-c.1890. In (D. Christensen, ed.) Yearbook for Traditional Music, 20, 1. New York: International Council for Traditional Music, Columbia University, 51-73.

Bor, J., Arnold, W.A., \& I. Mott (1984). Notating Hindustani Music. New Delhi: ISTAR Newsletter, 3-4., 29-42.

Brightman, P. (1984). Making dances with algorithms: towards a theory of choreography, based on the use of computer programs and Laban concepts. Submitted in partial fulfillment of the requirements for the Master of Arts Degree in Independant Study in Dance Composition Theory.

Brightman, P. (1989). Computers, choreography and creativity. AI'89 Conference, Prague.

Castellengo, M. (1991). Quelques aspects de la perception de la hauteur et du timbre dans un contexte musical. Colloque "Genèse et perception des sons". Cinquantenaire du Laboratoire de Mécanique et d'Acoustique, Marseille, 16-18 October. (Forthcoming)

Cogan, R. (1991). Composition: Diversity/Unity. In (O. Laske, guest ed.) Composition Theory. Interface, 20, 3-4, 137-141.

Cooke, P. (1991). Report on Pitch Perception Experiment carried out in Buganda and Busoga (Uganda) August 1990. Electronic file retrievable by anonymous ftp from info.umd.edu , directory ReadingRoom/Newsletters/EthnoMusicology/Digest.

Duncan, I. (1977). The Art of the Dance. New York: Theatre Art Books.

Esclapez, C. (1992). Le cas de l'expression temporelle dans les quatuors de Beethoven. In (E.Tarasti, ed.) Proceedings of the First International Doctoral Seminar on Musical Semiotrics. Imatra (Finland): International Semiotics Institute. (Forthcoming)

Frith, S. (1991, 5-7 December). The Naked and the Dead. Ethnicity and Authenticity and the Pop Pursuit of Non-Pop Music. Convegno Musica Colta e Musica Popolare: Una Convivenza Problematica, Cagliari (Italy). (Forthcoming)

Giurchescu, A., A.L. Kaeppler \& L. Torp (guest eds.) (1991). Yearbook for Traditional Music, 23. New York: International Council for Traditional Music.

Grossin, W. (1988) Pour une écologie temporelle. In (De Boeck, ed.) Les temps sociaux. Paris: Editions Universitaires.

Hall, E.T. (1983). The Dance of Life. New York: Anchor Press/Doubleday.

Jung, C.G. (1950). Foreword. In The I Ching or Book of Changes, Richard Wilhelm translation. London: Routledge.

Kawabata, Y. (1960). Pays de Neige. French translation: Bunkichi Fujimori \& Armel Guerne. Paris: Albin Michel.

Kikkawa, S. (1989). Nihonbuyo no riron, buvo no yoso, kozo, dosa no bunseki [Theory of Japanese dance, analysis of elements, structures and movements of dance]. In (S. Gamo et al., eds.) Nihon no ongaku, Ajia no ongaku [Japanese music, Asian music] vol.5. Tokyo: Iwanami shoten, 155-184.

Kippen, J. (1985). The dialectical approach: a methodology for the analysis of tabla music. Bulletin of the International Council for Traditional Music, UK Chapter.

Kippen, J. (1992). Where does the end begin? Problems in musico-cognitive modelling. Minds and Machines, 1 . (Forthcoming)

Kippen, J., \& B. Bel (1989a). Can the computer help resolve the problem of ethnographic description? Anthropological Quarterly, 62, 3, 131-140.

Kippen, J., \& B. Bel (1989b). The identification and modelling of a percussion "language", and the emergence of musical concepts in a machine-learning experimental set-up. Computers \& Humanities, 23, 3, 199-214. 
Kippen, J., \& B. Bel (1992). Modelling music with grammars: formal language representation in the Bol Processor. In (A. Marsden \& A. Pople, eds.) Computer Representations and Models in Music. London: Academic Press, 207-238.

Kirshenblatt-Gimblett, B. (1992). Confusing Pleasures. In (R. Schechner, ed.) Intercultural Performance. Routledge. (Forthcoming)

Krumm, P. (1991). Qu'est-ce que la World Music? Le Monde, 17/10/91, p.20.

Labesse, P. (1991). Le marché du disque. Idées longues et vision courte. Le Monde, 17/10/91, p.20.

Laske, O.E. (1992). Technology Management as Action Research: Challenges for Organizational Re-Education. CC-AI, 9,1. (Forthcoming)

Lath, M. (1984). Imagination créatrice et activité artistique "transformationnelle". Diogène, 127. Paris, 43-69.

Lath, M. (1988). What is Khyal? - a critique of Wade's "Khyal: Creativity within North India's Classical Music Tradition.” NCPA Quarterly Journal, XVII,1. Bombay: National Centre for the Performing Arts, 1-11.

Malinowski, B. (1922). Argonauts of the Western Pacific. An Account of Native Enterprise and Adventure in the Archipelagoes of Melanesian New Guinea. New York: E.P. Dulton \& co.

Morin, E. (1990). Introduction à la pensée complexe. Paris: ESF.

Nelson, S. (1992). (Untitled) response to Kirshenblatt (1992, supra). Ethnomusicology Research Digest (25 February). Electronic file retrievable by anonymous ftp from info.umd.edu directory ReadingRoom/Newsletters/EthnoMusicology/Digest.

Nettl, B. (1989). Mozart and the ethnomusicological study of Western Culture (an essay in four movements). Yearbook for Traditional Music, 21. New York: International Council for Traditional Music, 1-16.

Oertli, P. (1990). Percussion notation with "RHYTHMICS". Marseille: ICTM-ISTAR seminar Transcription of Traditional Music. (Unpublished)

Ohtani, K. (1991). Japanese Approaches to the Study of Dance. In (A. Giurchescu, L. Torp \& A.L. Kaeppler, guest eds.) Yearbook for Traditional Music, 23. New York: International Council for Traditional Music, Columbia University, 23-32.

Rao, S. (1992, forthcoming). Acoustical Perspective on Raga-Rasa Theory. $\mathrm{PhD}$ Thesis, S.N.D.T Women's University, Bombay.

Rao, S., \& D.B. Biswas (1990). Aesthetics of Hindustani Music - an Acoustical Study. In (B. Vecchione \& B. Bel, eds.) Le Fait Musical - Sciences, Technologies, Pratiques. Prepublication of the Acts of the Conference "Music and Information Technology", Aix-en-Provence/Marseille: CRSM-MIM, 465-490.

Schechner, R. (1991). Restoration of Behaviour. In Barba \& Savarese (1991), see supra, 205-235.

Servant, I. (1992). How was Time Represented? 17-18th Century Harpsichord Music in French Society. Third International Conference on Musical Signification, Edinburgh.

Shankar, R. (1991). Symphonie pour une fusion. Le Monde, 17/10/91, p.23.

Taviani, F. (1991). Views of the Performer and the Spectator. In Barba \& Savarese eds. (1991), see supra, 256-267.

Van der Meer, W., \& B. Bel (1986). Automatic Notation. Report to Study Group on Computer Retrieval, International Council for Traditional Music. Essen University (Germany). (Unpublished)

Vecchione, B. (1992). Rhétorique et musique: la dimension épidictique dans le Nuper Rosarum Flores Terribilis Est Locus Iste de Guillaume Dufay (1436). Third International Congress on Musical Signification, Edinburgh.

Walimbe, Y.S. (1980). Abhinavagupta on Indian Aesthetics. Ajanta's series on aesthetics, 2. Delhi: Ajanta.

Williams, D. (1981). Introductory Essay. Journal for the Anthropological Study of Human Movement, 1, 4. (Special issue on semiasology) 


\section{APPENDIX: A DISCUSSION OF INDIAN SCALES}

Formulating all implications of Bharata's two-vina experiment leads to a set of equations/inequations with three indeterminations (Bel 1988a, p.7). Indeed, the 22interval equal-tempered scale is a possible solution. But there are equally interesting sets of solutions (including scales with "flexible" intervals) derived from the same hypotheses by supplying three additional statements, e.g. the size of the 13-sruti interval (the consonant interval close to a just fifth), of the 7-sruti interval (resembling a harmonic major third, yet classified as anuvad - "assonant"), or even the size of the 22-sruti interval (the octave). Interesting scales may for instance be derived from an octave larger than 1200 cents, in agreement with psychoacoustic observations on octave tunings.

In a study of intervals used by several performers of raga Todi (Bel 1988b, 101-102) it was found that the scale model mentioned above could match experimental data in at least four different tuning schemes with an accuracy better than four cents. Each plausible tuning was based on two chains of perfect fifths and fourths and a "flexible" 7-sruti interval (major third) varying from 369 to 382 cents. However, none of these scales would be easy to tune on a stringed instrument. Wim van der Meer (personal communication) observed that, in the presence of a drone whose tonic we may call "C", a musician would easily tune $\mathrm{G}$ (a perfect ascending fifth), then B (a Pythagorean limma, i.e. 90 cents, below $\mathrm{C}$ ), then $\mathrm{F} \#$ and $\mathrm{Eb}$ from $\mathrm{G}$ (a perfect fifth and a harmonic major third, respectively), then $\mathrm{Ab}$ and $\mathrm{Db}$ as descending fifths from $\mathrm{Eb}$. The resulting tuning scheme may be represented:

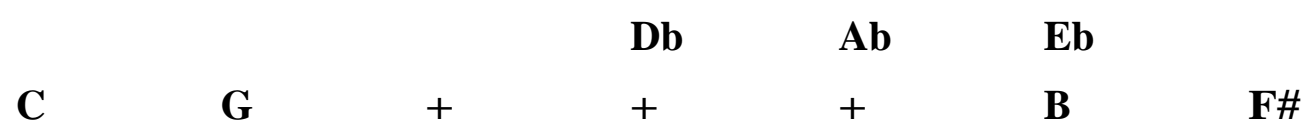

In this scheme, however, $\mathrm{F} \#$ to $\mathrm{Db}$ is a modal fifth ( 680 cents), too small by one comma (22 cents). Comparing our data with this model we found the following intervals:

$\begin{array}{llllllll} & \text { C-G } & \text { B-C } & \text { B-F\# } & \text { B-Eb } & \text { Ab-Eb } & \text { Bb-Ab } & \text { F\#-Db } \\ \text { theory } & 702 & 90 & 702 & 386 & 702 & 702 & 680 \\ \text { measured } & 702 & 93 & 699 & 387 & 702 & 697 & 689\end{array}$

In fact, if this model is correct (it does match musicians' practice accurately) then musicians would distribute equally the extra comma over the three fifths in the chain B$\mathrm{F} \#-\mathrm{Bb}-\mathrm{Ab}$.

It is therefore clear that a hypothetical tuning procedure cannot be validated just on the basis of analytical data. Additional experiments are needed for observing how musicians tune real sympathetic strings, and the tonal relations that they (think) they establish in this way. Such experiments require an awareness of the task-dependency of tuning decisions: musicians requested to assess different scale tunings may not achieve the same accuracy depending on whether or not they are given the opportunity to adjust the instrument's tuning themselves (Cooke 1991, Bel 1991). 
Bernard Bel

GRTC, Centre National de la Recherche Scientifique

31 chemin Joseph Aiguier

F-13402 Marseille Cedex 09

E-mail: bel@grtc.cnrs-mrs.fr

Fax: (033) 91710808

Bernard Bel is a doctor in computer science with background in electronics. A founder member of the International Society for Traditional Arts Research (ISTAR), he has long been associated with anthropologists, musicologists and musicians on a scientific study of North Indian melodic and rhythmic systems. In 1981 he built an accurate real-time Melodic Movement Analyser (MMA) allowing automatic transcription and analysis of raga music. In 1986 he joined GRTC, an AI laboratory of the Centre National de la Recherche Scientifique in Marseille. At present he is working (in collaboration with ethnomusicologist Jim Kippen) on language inference techniques for the simulation of traditional and contemporary drum improvisation. Bernard Bel is a founder member of the International Association for Knowledge Technology in the Arts (IAKTA) and is currently teaching computational musicology at the Department of Music, Provence University.

Andréine Bel

c/o ISTAR France

37 rue Boudouresque

F-13007 Marseille

Having studied classical ballet, Andréine Bel began investigating "laws of human movement" under the guidance of Seïtaï expert Itsuo Tsuda and Raymond Duncan's disciple François Malkovsky in 1973-74. She continued on her own and felt the need to develop dance and expression techniques in a thorough study of North Indian Kathak, for which she joined the school of Pandit Birju Maharaj in 1978. In 1986 she returned to Europe and completed her study of Indian languages and civilizations at Aix-en-Provence University under the direction of Prof. Jean Naudou. In 1988 she founded the Atelier de Recherche Rythmique et Chorégraphique (ARRC) in Marseille, in collaboration with French composer André Mouret and ethnomusicologist Jim Kippen. The winner of a prize in choreography/scenography with $L a$ Légende d'Ys, she has produced a broad variety of "fusion" dance items using classical, contemporary and extra-European music. She also directed actors' gestures in theatre groups, participated in video/dance/sculpture/poetry performances and worked with physically and mentally disabled people. 